\title{
PERAN PERCEIVED RISK DALAM MEMEDIASI PENGARUH PERCEIVED QUALITY TERHADAP PERCEIVED VALUE
}

\author{
Desak Ayu Made Eva Suari Adnyani ${ }^{1}$ \\ I Putu Gde Sukaatmadja ${ }^{2}$
}

${ }^{1,2}$ Fakultas Ekonomi dan Bisnis Universitas Udayana (Unud), Bali, Indonesia email: evasuari@gmail.com

\begin{abstract}
ABSTRAK
Tujuan penelitian ini adalah untuk menguji peran perceived risk dalam memediasi pengaruh perceived quality terhadap perceived value pada nasabah LPD Desa Adat Jro Kuta Pejeng. Populasi penelitian ini adalah LPD Desa Adat Jro Kuta Pejeng yang tinggal di daerah Desa Pejeng. Sampel sebanyak 110 reponden ditentukan menggunakan metode purposive sampling. Metode pengumpulan data menggunakan metode angket berupa kuesioner. Teknik analisis yang digunakan adalah teknik analisis jalur (analysis path) dan uji sobel. Hasil análisis menunjukkan bahwa perceived quality berpengaruh negatif signifikan terhadap perceived risk, perceived quality berpengaruh positif signifikan terhadap perceived value, perceived risk berpengaruh negatif signifikan terhadap perceived value, dan perceived risk berpengaruh positif signifikan sebagai mediasi pada pengaruh perceived quality terhadap perceived value.
\end{abstract}

Kata kunci: perceived quality, perceived value, perceived risk

\begin{abstract}
The purpose of this study was to examine the role of perceived risk in mediating the effect of perceived quality on perceived value on customers of LPD Adat Jro Kuta Pejeng Village. The population of this study was LPD Adat Jro Village Kuta Pejeng who lived in the Pejeng Village area. A sample of 110 respondents was determined using the purposive sampling method. Methods of data collection using the questionnaire method in the form of a questionnaire. The analysis technique used is path analysis technique (analysis path) and sobel test. The results of the analysis show that perceived quality has a significant negative effect on perceived risk, perceived quality has a significant positive effect on perceived value, perceived risk has a significant negative effect on perceived value, and perceived risk has a significant positive effect as a mediation the effect of perceived quality on perceived value.

Keywords: perceived quality, perceived value, perceived risk
\end{abstract}




\section{PENDAHULUAN}

Pertumbuhan ekonomi di Indonesia tidak terlepas dari peran pemerintah daerah dalam menggerakkan perekonomian. Daerah Bali yang memiliki desa yang kental budaya adat-istiadat, di mana dikenal sebagai masyarakat desa pekraman. Keberadaan masyarakat desa pekraman mendasari berdirinya lembaga keuangan milik desa yang disebut dengan Lembaga Perkreditan Desa (LPD). LPD merupakan lembaga keuangan yang melayani masyarakat desa pekraman mengalokasikan keuntungan dari kegiatannya untuk kepentingan dari masyarakat desa pekraman yang bersangkutan, dengan kata lain keuntungan yang diperoleh oleh LPD akan kembali dan dirasakan oleh seluruh masyarakat desa pekraman.

Melalui Surat Keputusan Gubernur Provinsi Bali No.927 Tahun 1984, LPD dibentuk sebagai integrasi dan membantu masyarakat desa dalam meningkatkan usaha ekonomi (Karwini \& Suryanto, 2016). Keberadaan LPD pertama kali dilandasi oleh Perda Tingkat I Bali No.6 Tahun 1986 dengan tujuan mengatasi masalah permodalan yang dialami krama desa adat dalam mengembangkan usaha kecil, kemudian diatur dibawah Peraturan Daerah (Perda) Provinsi Bali Nomor 8 Tahun 2002 Tentang Lembaga Perkreditan Desa (LPD), yang kini telah diganti menjadi Perda Provinsi Bali Nomor 3 Tahun 2017. LPD di Bali berkembang dengan sangat cepat, terbukti dengan banyaknya LPD yang ada, dari tahun ke tahun seperti pada tahun 1984 di mana pada awal dibentuknya LPD hanya ada 8 (delapan) LPD di Bali, jumlah tersebut mengalami peningkatan dari tahun ke tahun. Kemudian pada tahun 1990 ada 341 unit LPD, tahun 2005 menjadi 1304 unit dan ditahun 2016 ada sebanyak 1433 unit LPD ("Potret LPD di Bali Kekayaan Rp 155 T Bangkrut Terbanyak di Tabanan,” 2017). Lembaga Pemberdayaan-Lembaga Perkreditan Desa Provinsi Bali (2017) lebih dikenal LPLPD Provinsi Bali menyatakan total aset LPD mencapai Rp 15,5 trilyun, melibatkan pengurus dan karyawan LPD sebanyak 7.882 orang. Perkembangan LPD juga ditunjukkan pada tahun 2017, di mana aset LPD naik sebesar 22,5

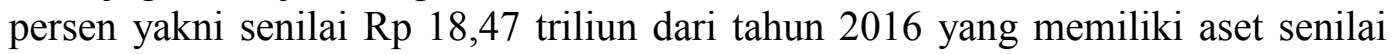
Rp 16,06 triliun (Kristanto, 2018).

Peningkatan aset LPD tidak terlepas dari peran masyarakat untuk menabung di LPD karena memiliki kepercayaan. Perkembangan LPD yang paling pesat salah satunya adalah LPD di Kabupaten Gianyar. Sebagai salah satu LPD yang berkembang pesat, Kabupaten Gianyar menjadi lokasi yang paling banyak memiliki Lembaga keuangan mikro milik desa dan nilai aset tinggi yakni sebanyak 124 unit (Kristanto, 2018). Pemerintah daerah juga berperan mendorong perkembangan LPD dengan pengadaaan dana penjaminan simpanan, dana perlindungan, dana penyangga likuiditas, selain itu LPD membantu menyerap tenaga kerja yang ada. Keanggotaan LPD secara struktural, terdiri atas beberapa banjar. Artinya keberadaan LPD ditopang oleh krama desa bersangkutan (Gunawan, 2011).

Upaya LPD dalam mendorong perkembangan yakni menggunakan landasan operasional berdasarkan rasa kekeluargaan dan gotong royong serta kebijakan awig-awig desa pekraman, sehingga mampu meningkatkan kepercayaan masyarakat desa pekraman (Karwini \& Suryanto, 2016). Dalam pelaksanaan operasionalnya, dana dikumpulkan LPD dalam bentuk tabungan dan deposito, 
serta memberikan pinjaman dalam bentuk kredit (Yanti \& Suryantini, 2015). LPD terus dikembangkan untuk menjadi lembaga keuangan mikro milik desa pekraman yang kuat dan sehat, tetapi tidak semua LPD memiliki kinerja keuangan yang sehat. Tercatat sebanyak 38 unit LPD dinyatakan masuk kategori tidak sehat. Hal tersebut disebabkan karena LPD masih memiliki keterbatasan sumber daya manusia dan pengalaman kerja (Martini \& Kepramarini, 2015).

Keterbatasan sumber daya manusia dan pengalaman kerja menyebabkan masih saja adanya LPD yang kurang sehat dan macet (Yanti \& Suryantini, 2015), selain itu kurangnya ketaatan LPD dalam menerapkan sistem manajemen, dan penyaluran kredit yang kurang hati-hati memerlukan perhatian sendiri (Sadiartha, 2017). Dalam beberapa kasus bahkan ada LPD yang sampai tidak beroperasional, dengan kata lain mengalami kebangkrutan. Isu - isu yang terjadi dapat memberikan pendapat yang berbeda pada masyarakat tentang LPD.

LPD membangun nilai (value) dengan memberikan pinjaman dengan syarat yang tidak rumit seperti bank, serta mereka tidak perlu jauh-jauh ke bank karena lokasi LPD relatif dekat dengan rumah masyarakat (Suarni et al., 2014). Nilai yang diberikan nasabah berhubungan dengan benefit atau keuntungan yang akan diterimanya (Hidayat, 2009). LPD Desa Adat Jro Kuta Pejeng berupaya membangun nilai dengan memberikan bantuan dana pada pelaksanaan upacara desa adat, serta kredit tanpa anggunan. Kepengurusan LPD terdiri atas pengurus dan pengawas dari desa, membentuk kepercayaan masyarakat dalam menyimpan tabungan dan deposito sehingga memberikan nilai tambah bagi LPD.

LPD merupakan lembaga yang didirikan dan dikelola secara intern oleh desa pekraman (Surata, 2011). Membangun perceived value yang tinggi pada nasabah juga diperlukan produk dan jasa yang berkualitas, seperti pada penelitian Utomo \& Sanaji (2014) yang menyatakan bahwa perceived quality berpengaruh positif signifikan terhadap perceived value. Hal ini berarti untuk membangun perceived value yang tinggi, perusahaan harus memberikan perceived quality yang tinggi pada nasabah. Cara lain yang digunakan untuk meningkatkan perceived value nasabah LPD ialah memberikan pelayanan antar jemput pada nasabah yang melakukan tabungan harian dan pembayaran kredit.

Menurut Choi \& Kim (2013) persepsi nasabah terhadap kualitas produk dan jasa mempengaruhi value, dan penilaian positif terhadap suatu produk menciptakan persepsi positif terhadap suatu produk. Menurut Kurniawan \& Idris (2015) nasabah memberikan penilaian terhadap jasa melalui berbagai informasi yang digunakan sehingga dapat mewujudkan kualitas suatu jasa. Pelayanan yang diberikan oleh LPD sudah memenuhi kebutuhan nasabah (masyarakat desa) yakni prosedur yang sederhana, proses yang singkat, pendekatan personal, serta kedekatan lokasi dengan nasabah (Sundarianingsih, 2014). Perceived quality adalah persepsi pelanggan atas kualitas layaanan saat menerima pelayanan (Wijaya et al., 2013). Perceived quality produk LPD didapatkan dengan cara menemukan keseluruhan harapan nasabah, meningkatkan nilai pelayanan dalam rangka memenuhi harapan nasabah tersebut (Hidayat, 2009). Perusahaan yang mampu menjaga kualitas pelayanan (perceived quality) akan dapat menjaga hubungan dengan nasabah menjadi baik. 
Tentunya nasabah memiliki kekhawatiran tentang risiko (perceived risk) yang dihadapi ketika menggunakan jasa LPD. Risiko merupakan suatu keadaan uncertainty yang dipertimbangkan orang untuk memutuskan atau tidak melakukan transaksi. Kerugian mungkin akan dihadapi nasabah ketika menggunakan suatu produk atau jasa. Pandangan nasabah akan adanya dampak negatif yang akan timbul dan hasil yang diharapkan menyimpang tentang kinerja LPD menyebabkan timbulnya risiko (Sari et al., 2015).

Dalam beberapa kasus, informasi negatif tentang LPD seperti penyelewengan modal finansial, kecurangan dalam transaksi, serta kebangkrutan (Suaslioni et al., 2017), dapat mempengaruhi pandangan nasabah tentang risikonya. Berdasarkan penelitian sebelumnya yang dilakukan oleh (Snoj et al., 2004) menyatakan bahwa perceived quality berpengaruh negatif signifikan terhadap perceived risk, sejalan dengan (Beneke et al., 2013). Berbeda dengan penelitian Snoj et al. (2004) dan Beneke et al. (2013), penelitian yang dilakukan oleh Marakanon \& Panjakajornsak (2017) menyatakan bahwa perceived quality berpengaruh positif signifikan terhadap perceived risk.

Penelitian selanjutnya menyatakan bahwa perceived risk berpengaruh negatif signifikan terhadap perceived value (Beneke et al., 2013). Penelitian tersebut di dukung oleh Xue (2015) yang menemukan hasil perceived risk berpengaruh negatif signifikan terhadap perceived value. Berbeda dengan hasil penelitian yang dilakukan oleh Naami et al. (2017) menemukan bahwa perceived risk berpengaruh positif signifikan terhadap perceived value. Adanya gap penelitian tentang peran perceived risk dalam memediasi pengaruh perceived quality terhadap perceived value (studi pada nasabah LPD Desa Adat Jro Kuta Pejeng) menarik untuk diteliti. Hal lain seperti perkembangan LPD yang cukup cepat, membuat jasa keuangan non bank lainnya seperti koperasi akan berusaha dengan segala cara untuk memperoleh nasabah sehingga membentuk perceived value yang berbeda, juga membuat peneliti termotivasi untuk melakukan penelitian ini.

Sejak dikenalkan di Bali tentang LPD melalui Surat Keputusan Gubernur Provinsi Bali No.927 Tahun 1984. Menurut Karwini \& Suryanto (2016) LPD dibentuk untuk mengintegrasi dan membantu masyarakat desa dalam meningkatkan usaha ekonomi. Dalam perkembangannya undang-undang yang mengatur tentang LPD juga mengalami perubahan, dimana pertama kali diatur dalam Perda Provinsi Bali No.2 Tahun 1988, mengalami perubahan kedua menjadi Perda Provinsi Bali No.8 Tahun 2002, dan yang terbaru menjadi Perda Provinsi Bali Nomor 3 Tahun 2017. LPD merupakan lembaga keuangan yang melayani masyarakat desa pekraman mengalokasikan keuntungan dari kegiatannya untuk kepentingan dari masyarakat desa pekraman yang bersangkutan, dengan kata lain keuntungan yang diperoleh oleh LPD akan memberikan manfaat yang dirasakan kembali oleh seluruh masyarakat desa pekraman.

Bali sebagai salah satu provinsi di Indonesia memiliki budaya yang kental, begitu juga penggerak roda ekonominya yang tidak berlandaskan sumber daya alam melainkan sumber daya budaya. Desa adat atau desa pekraman sebagai masayarakat yang mempunyai tata susunan asli yang sudah lama dan sangat perlu 
dijaga dan dilestarikan eksistensinya (Rauf, 2016). Pemeliharaan sumber daya budaya dalam upaya menggerakkan perekonomian, masyarakat desa pekraman memiliki tanggung jawab tersebut.

LPD Desa Adat Jro Kuta Pejeng berdiri pada tanggal 10 Pebruari 2009 yang aktif hingga saat ini dan beralamat di jalan Dr Ir Soekarno, Pejeng, Tampaksiring, Gianyar memiliki pengawas dari Bendesa Adat yakni Cok Gede Putra Pemayun,SH dan ketua LPD yakni Tjok Agung Kesuma Yuda, SE. Tujuan berdiri dari LPD Desa Adat Jro Kuta Pejeng dilandaskan oleh Perda Provinsi Bali No.3 Tahun 2017 yakni, 1) mendorong pembangunan ekonomi warga Desa Pekraman Pejeng melalui kredit dan tabungan, 2) memberantas ijon, dan 3) pemerataan lapangan kerja bagi warga Desa Pekraman Pejeng. Kegiatan lainnya, LPD Desa Adat Jro Kuta Pejeng menggunakan 20 persen keuntungan untuk mendanai kegiatan sosial di desa setempat seperti pembangunan pura, pendanaan pelaksanaan upacara, dan kegiatan sosial lainnya.

LPD Desa Adat Jro Kuta Pejeng mengalami perkembangan yang pesat ditunjukkan dengan nilai asetnya sekitar Rp 23 miliyar serta jumlah nasabah saat ini sebanyak 3.036 orang nasabah, yang terdiri atas 2.419 nasabah tabungan dan 617 nasabah kredit. Kepercayaan masyarakat desa pekraman Pejeng membantu mendorong perkembangan LPD, selain itu dengan adanya LPD Desa Adat Jro Kuta Pejeng tenaga kerja yang tersedia di Desa Pejeng dapat dipekerjakan yang mendorong pemerataan kesempatan kerja.

LPD memiliki beberapa tujuan, yaitu; 1) mendorong pembangunan ekonomi masyarakat desa melalui kredit dan tabungan, 2) memberantas sistem ijon, 3) menciptakan pemerataan dan kesempatan kerja bagi warga desa pekraman (Ramantha, 2003). LPD berkembang dengan pesat dan telah memberi manfaat yang luas bagi desa pekraman, dan seiring dengan itu timbul berbagai kebutuhan baru berkenaan dengan eksistensi kelembagaan, unsur-unsur manajemen, kegiatan dan operasionalnya. Dalam Perda Provinsi Bali No.3 Tahun 2017 juga menyebutkan bahwa organisasi LPD terdiri dari prajuru desa dan panureksa. Prajuru desa yang dimaksudkan adalah pengurus desa pekraman, dan panureksa dalam organisasi dimaksudkan dengan badan pengawas internal yang dibentuk oleh desa pekraman bertugas melakukan pengawasan terhadap pengelolaan LPD.

Bali sebagai salah satu provinsi di Indonesia memiliki budaya yang kental, begitu juga penggerak roda ekonominya yang tidak berlandaskan sumber daya alam melainkan sumber daya budaya. Desa adat atau desa pekraman sebagai masayarakat yang mempunyai tata susunan asli yang sudah lama dan sangat perlu dijaga dan dilestarikan eksistensinya (Rauf, 2016). Pemeliharaan sumber daya budaya dalam upaya menggerakkan perekonomian, masyarakat desa pekraman memiliki tanggung jawab tersebut.

Menurut Dewi (2014) desa pekraman merupakan lembaga bersifat tradisional yang memiliki corak religius dan pemerintahannya bersifat otonom berdasarkan hak asal-usulnya. Peraturan Daerah Provinsi Bali No.8 Tahun 2002 menyebutkan desa pekraman adalah kesatuan masyarakat hukum adat di Provinsi Bali yang mempunyai satu kesatuan tradisi dan tata pergaulan hidup masyarakat umat hindu secara turun temurun dalam ikatan khayangan desa yang mempunyai 
wilayah tertentu dan harta kekayaan sendiri serta berhak mengurus rumah tangganya sendiri.

Perceived quality adalah penilaian subjektif indvidu terhadap kualitas objektif (Yang \& Wang, 2014). Perceived quality adalah persepsi kualitas tentang suatu produk yang menyebabkan seseorang apakah niat atau tidak dalam membeli suatu produk, di mana perceived quality sebagai pertimbangan konsumen dalam menggunakan suatu produk (Indrayani \& Nurcaya, 2014). Menurut (Tsiotsou, 2005) perceived quality merupakan penilaian konsumen tentang keunggulan keseluruhan produk.

Lomboan (2017) menyatakan perceived quality adalah penilaian subjektif seseorang terhadap suatu kualitas jasa atau produk dan di evaluasi berdasarkan pengalaman dan perasaan mereka sebelumnya. Ini berarti membangun perceived quality sangat penting, karena dapat menunjukkan keunggulan kualitas pelayanan yang kita tawarkan. Layanan yang baik (perceived quality) akan memperoleh nilai yang dikehendaki oleh pelanggan (Kotler, 2000). Menurut Zheithaml dalam Lee (2017) perceived quality merupakan evaluasi subjektif keunggulan produk secara keseluruhan didasarkan manfaat yang diberikan sebagai ukuran standar. Menurut Yamin (2013) perceived quality merupakan persepsi nasabah terhadap kualitas suatu jasa layanan berkaitan dengan apa yang diharapkan oleh nasabah.

Value memiliki ikatan yang kuat dengan persepsi, karena manfaat yang diterima dengan biaya yang dikeluarkan akan mempengaruhi dalam membentuk perceived value. Perceived value adalah nilai yang diharapkan dan dirasakan oleh konsumen (Ikramuddin et al., 2017). Menurut Lai (2004) perceived value adalah penilaian konsumen terhadap keseluruhan terhadap manfaat produk, didasarkan dari apa yang diterima dan apa yang diberikan. Naami et al. (2017) menyatakan bahwa perceived value merupakan fungsi kualitas dan harga yang dirasakan oleh pelanggan. Dalam Ariyanti \& Iriani (2014) perceived value merupakan penilaian konsumen tentang suatu produk atau jasa dengan membandingkan manfaat (value) dan pengorbanan yang dilakukan untuk memperoleh barang atau jasa. Perceived value merupakan usaha nasabah dalam memberikan penilaian dan membandingkan produk atau jasa dari perusahaan tertentu dengan perusahaan pesaing lainnya (Kurniawan \& Idris, 2015). Nilai yang dirasakan adalah konsumen mengevaluasi semua manfaat dari produk atau layanan atau memahami sebanyak yang ia peroleh dari apa yang diberikan kepadanya (Akdeniz, 2015). Menurut (Hapsari et al., 2016) menyatakan bahwa semakin sedikit pengorbanan yang dilakukan dibandingkan dengan kualitas yang mereka terima, maka akan semakin tinggi perceived value. Menurut Utomo \& Sanaji (2014) perceived value memiliki 5 (lima) dimensi yaitu 1) nilai fungsional, 2) nilai sosial, 3) nilai emosional, 4) nilai epistemic, dan 5) nilai kondisional.

Menurut (Sciffman \& Kanuk, 2008:137), risiko yang dirasakan didefinisikan sebagai ketidakpastian yang dihadapi para konsumen jika mereka tidak dapat meramalkan konsekuensi keputusan pembelian mereka. Perceived risk adalah pandangan tentang adanya dampak negatif yang mucul (Sari et al., 2015). Menurut Bobalca (2014) perceived risk adalah persepsi konsumen mengenai konsekuensi atau dampak negatif setelah melakukan pembelian jasa. Perceived risk merupakan risiko yang dirasakan secara nyata dalam proses pembelian 
produk atau jasa, menimbulkan konsekuensi melalui keraguan atau ketidakpastiaan (Xue, 2015). Menurut Peter dan Olson dalam Ariyanti \& Iriani (2014) mengatakan bahwa perceived risk, risiko terduga merupakan risiko yang tidak diharapkan yang ingin dihindari ketika membeli produk atau menggunakan jasa.

Nilai (value) nasabah sangat dipengaruhi oleh perceived quality terhadap produk atau jasa yang ditawarkan oleh perusahaan. Dalam penelitian (Wijaya et al., 2013) menemukan hasil bahwa perceived quality berpengaruh positif signifikan terhadap perceived value pengguna internet mobile. Artinya bila persepsi terhadap kualitas meningkat, maka perceived value pengguna akan meningkat secara signifikan, serta penelitian yang dilakukan Utomo \& Sanaji (2014) menemukan hasil perceived quality berpengaruh positif signifikan terhadap perceived value produk telepon seluler. Penelitian Najib et al. (2016) juga menyatakan bahwa perceived quality berpengaruh positif signifikan terhadap perceived value. Berdasarkan uraikan diatas maka rumusan hipotesis sebagai berikut:

$\mathrm{H}_{1}$ : perceived quality berpengaruh positif signifikan terhadap perceived value

Nilai nasabah dibentuk oleh perceived quality dan perceived risk. Nasabah memberikan nilai tentang jasa yang memiliki keunggulan (Tsiotsou, 2005). (Snoj et al., 2004) menemukan bahwa perceived quality berpengaruh negatif signifikan terhadap perceived risk. Hal tersebut juga ditemukan dalam penelitian Beneke et al. (2013) yang menyatakan bahwa perceived quality berpengaruh negatif signifikan terhadap perceived risk, serta penelitian Wang \& Yi (2015) menyatakan perceived quality berpengaruh negatif signifikan terhadap perceived risk. Berdasarkan uraian tersebut maka:

$\mathrm{H}_{2}$ : perceived quality berpengaruh negatif signifikan terhadap perceived risk

Dalam membeli barang atau jasa terdapat hal yang tidak pasti (risk) sehingga menimbulkan kekhawatiran bagi seseorang. Penelitian Xue (2015) menyatakan perceived risk adalah risiko yang dirasakan secara nyata setelah proses pembelian barang atau jasa. Snoj et al. (2004) menemukan perceived risk berpengaruh negatif signifikan terhadap perceived value. Dalam penelitian dilakukan Yang \& Wang (2014) menemukan bahwa dimensi-dimensi perceived risk berpengaruh negatif terhadap perceived value, serta Xue (2015) bahwa perceived risk berpengaruh negatif signifikan terhadap perceived value.

$\mathrm{H}_{3}$ : perceived risk berpengaruh negatif signifikan terhadap perceived value

Perceived risk yang semakin rendah menunjukkan perceived quality yang tinggi sehingga dapat membangun perceived value nasabah yang tinggi. Menurut Snoj et al. (2004) penelitian pengaruh perceived quality terhadap perceived value yang dimediasi oleh perceived risk, berpengaruh secara positif signifikan. Sejalan dengan penelitian (Snoj et al., 2004), penelitian Vera (2015) menemukan hasil perceived risk memediasi pengaruh perceived quality terhadap perceived value secara positif signifikan. Penelitian yang dilakukan oleh Agrawal \& Teas (2004) menemukan hasil bahwa performance risk memaediasi pengaruh perceived quality terhadap perceived value secara positif signifikan. Berdasarkan uraian diatas maka ditentukan hipotesis sebagai berikut: 
$\mathrm{H}_{4}$ : perceived risk memediasi pengaruh perceived quality terhadap perceived value secara positif signifikan.

\section{METODE PENELITIAN}

Dalam penelitian ini bukti empiris dipilih LPD Desa Adat Jro Kuta Pejeng, karena mengalami perkembangan yang baik ditengah persaingan jasa keuangan seperti koperasi yang mencoba membangun perceived value yang tinggi, selain itu ,ditengah isu penggelapan dana yang dilakukan di LPD lainnya, LPD Desa Adat Jro Kuta Pejeng dapat mempertahankan nasabah dengan perceived quality serta perceived value yang diberikan.

Populasi dalam penelitian ini adalah nasabah yang menggunakan jasa keuangan mikro LPD Desa Adat Jro Kuta Pejeng yang tinggal di daerah Desa Pejeng. Penentuan sampel yang representatif adalah jumlah indikator dikalikan 5 sampai dengan 10, dikarenakan jumlah indikator yang digunakan dalam penelitian ini berjumlah 11 maka ukuran sampelnya 11 x $10=110$ orang responden.

Teknik analisis yang digunakan dalam penelitian ini menggunakan Teknik analisis jalur. Hubungan antar variabel teoritis dapat dirumuskan ke dalam model persamaan structural dalam rumus 1 dan 2 serta gambar model analisis jalur pada penelitian ini.

Persamaan Sub-struktural 1

$$
\mathrm{M}=\beta_{1} \mathrm{X}+\mathrm{e}
$$

Persamaan Sub-struktural 2

$$
\begin{array}{ll}
\mathrm{Y}=\beta_{2} \mathrm{X}+\beta_{3} \mathrm{M} & + \text { e } \ldots \ldots \ldots \ldots \ldots \ldots \ldots \ldots \\
\text { Keterangan: } & \\
\mathrm{Y} & =\text { Perceived value } \\
\mathrm{X} & =\text { Perceived quality } \\
\mathrm{M} & =\text { Perceived risk } \\
\beta_{1}, \beta_{2}, \beta_{3} & =\text { koefisien regresi varibel } \\
\mathrm{e} & =\text { error }
\end{array}
$$

\section{HASIL DAN PEMBAHASAN}

Tabel 1. menunjukkan bahwa nilai total rata-rata skor jawaban responden pada variabel perceived quality yang diukur dengan delapan indikator, sebesar 3,65 sehingga masuk dalam kriteria baik. Berdasarkan hasil keseluruhan jawaban responden, responden setuju bahwa LPD Desa Adat Jro Kuta Pejeng memberikan pelayanan yang baik seperti, kondisi fisik LPD yang terjaga kebersihannya, karyawan memiliki penampilan yang rapi saat melayani nasabah, LPD Desa Adat Jro Kuta Pejeng mampu memberikan pelayanan yang segera, LPD Desa Adat Jro Kuta Pejeng memberikan pelayanan yang akurat, Karyawan LPD bersikap sigap dalam mengatasi keluhan nasabah, karyawan LPD memberikan penjelasan tentang kredit jangka panjang, dan karyawan LPD melayani dengan penuh perhatian.

Variabel perceived risk pada penelitian ini merupakan variabel mediasi yang diukur dengan empat pernyataan yang berhubungan dengan perceived risk pada nasabah LPD Desa Adat Jro Kuta Pejeng. Berikut dibawah ini rincian hasil jawaban responden terhadap perceived risk. Berdasarkan data Tabel 2. dapat dilihat bahwa nilai total rata-rata skor responden pada variabel perceived risk 
adalah sebesar 3,09 yang artinya termasuk kriteria cukup tinggi. Hal ini berarti responden merasa adanya risiko yang cukup tinggi dalam melakukan transaksi pada LPD Desa Adat Jro Kuta pejeng, dari empat indikator nilai rata-rata skor tertinggi adalah nasabah merasa dirugikan bila adanya kesalahan pencatatan pada saat melakukan transaksi yang memperoleh skor sebesar 3,59 dan skor rata-rata terendah dengan nilai sebesar 2,83 pada indikator nasabah merasa kurang percaya diri menggunakan jasa pelayanan.

Tabel 1.

Deskripsi Jawaban Responden Terhadap Variabel Perceived Quality

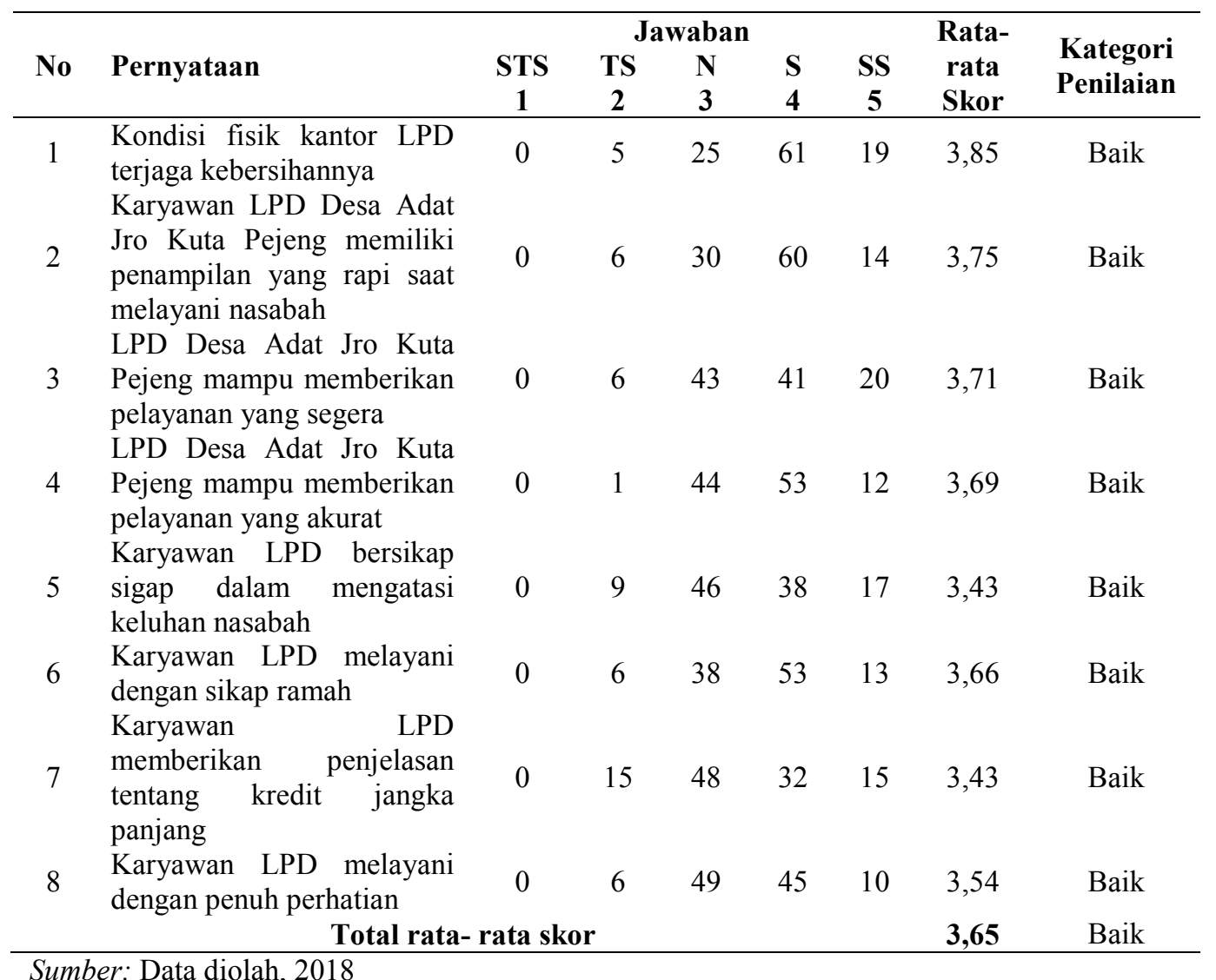

Dalam penelitian ini, perceived value sebagai variabel terikat yang diukur dengan empat pernyataan yang berhubungan dengan perceived value. Berikut Tabel 3. rincian jawaban responden terhadap variabel perceived value.

Pada Tabel 3. tentang rincian jawaban responden pada variabel perceived value, dapat dilihat bahwa nilai total rata-rata skor dari empat pernyataan adalah 3,62 termasuk kriteria tinggi. Hal ini berarti bahwa responden merasa bahwa LPD Desa Adat Jro Kuta Pejeng memberi manfaat yang tinggi ketika melakukan transaksi, dari keempat indikator, indikator yang memperoleh nilai skor rata-rata tertinggi adalah nasabah memperoleh manfaat saat melakukan transaksi di LPD dengan jumlah skor sebesar 3,71. Indikator lainnya yakni kualitas jasa atau produk simpanan LPD sangat bermanfaat bagi nasabah memperoleh nilai skor rata-rata terendah yakni 3,49 dari empat indikator yang ada. 
Tabel 2.

Deskripsi Jawaban Responden Terhadap Variabel Perceived Risk

\begin{tabular}{|c|c|c|c|c|c|c|c|c|}
\hline \multirow[b]{2}{*}{ No } & \multirow[b]{2}{*}{ Pernyataan } & \multicolumn{5}{|c|}{ Jawaban } & \multirow{2}{*}{$\begin{array}{l}\text { Rata- } \\
\text { rata } \\
\text { Skor }\end{array}$} & \multirow[b]{2}{*}{$\begin{array}{l}\text { Kategori } \\
\text { Penilaian }\end{array}$} \\
\hline & & $\begin{array}{c}\text { STS } \\
1\end{array}$ & $\begin{array}{c}\text { TS } \\
2\end{array}$ & $\begin{array}{l}\mathbf{N} \\
\mathbf{3}\end{array}$ & $\begin{array}{l}S \\
4\end{array}$ & $\begin{array}{c}\text { SS } \\
5\end{array}$ & & \\
\hline 1 & $\begin{array}{l}\text { Biaya Administrasi } \\
\text { LPD tinggi }\end{array}$ & 1 & 31 & 52 & 25 & 1 & 2,95 & $\begin{array}{l}\text { Cukup } \\
\text { tingoi }\end{array}$ \\
\hline 2 & $\begin{array}{l}\text { Nasabah mengalami } \\
\text { kerugian uang saat tidak } \\
\text { dapat melakukan } \\
\text { transaksi tabungan }\end{array}$ & 1 & 45 & 28 & 24 & 12 & 3,01 & $\begin{array}{l}\text { Cukup } \\
\text { tinggi }\end{array}$ \\
\hline 3 & $\begin{array}{lrr}\text { Nasabah } & & \text { merasa } \\
\text { dirugikan } & \text { bila adanya } \\
\text { kesalahan } & \text { pencatatan } \\
\text { pada saat } & \text { melakukan } \\
\text { transaksi } & & \end{array}$ & 1 & 6 & 42 & 49 & 12 & 3,59 & Tinggi \\
\hline 4 & $\begin{array}{lr}\text { Nasabah merasa kurang } \\
\text { percaya } & \text { diri } \\
\text { menggunakan } & \text { jasa } \\
\text { pelavanan } & \end{array}$ & 10 & 32 & 38 & 27 & 3 & 2,83 & $\begin{array}{l}\text { Cukup } \\
\text { tinggi }\end{array}$ \\
\hline & Total & a- ra & kor & & & & 3,09 & Cukup \\
\hline
\end{tabular}

Sumber: Data diolah, 2018

Tabel 3.

Deskripsi Jawaban Responden Terhadap Variabel Perceived Value

\begin{tabular}{|c|c|c|c|c|c|c|c|c|}
\hline \multirow[b]{2}{*}{ No } & \multirow[b]{2}{*}{ Pernyataan } & \multicolumn{5}{|c|}{ Jawaban } & \multirow{2}{*}{$\begin{array}{l}\text { Rata- } \\
\text { rata } \\
\text { Skor }\end{array}$} & \multirow{2}{*}{$\begin{array}{l}\text { Kategori } \\
\text { Penilaian }\end{array}$} \\
\hline & & $\begin{array}{c}\text { STS } \\
1 \\
\end{array}$ & $\begin{array}{c}\text { TS } \\
2\end{array}$ & $\begin{array}{l}\mathbf{N} \\
\mathbf{3}\end{array}$ & $\begin{array}{l}S \\
4 \\
\end{array}$ & $\begin{array}{c}\text { SS } \\
5\end{array}$ & & \\
\hline 1 & $\begin{array}{ll}\text { Nasabah merasa puas saat } \\
\text { menggunakan } & \text { jasa } \\
\text { pelayanan tabungan } & \text { dan } \\
\text { kredit LPD } & \end{array}$ & 0 & 5 & 36 & 57 & 12 & 3,69 & Tinggi \\
\hline 2 & $\begin{array}{l}\text { Kualitas jasa atau produk } \\
\text { simpanan LPD sangat } \\
\text { bermanfaat bagi nasabah }\end{array}$ & 0 & 11 & 46 & 41 & 12 & 3,49 & Tinggi \\
\hline 3 & 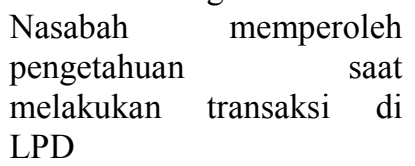 & 0 & 9 & 44 & 42 & 15 & 3,57 & Tinggi \\
\hline 4 & $\begin{array}{l}\text { Nasabah memperoleh } \\
\text { manfaat saat melakukan } \\
\text { transaksi di LPD }\end{array}$ & 0 & 8 & 27 & 64 & 11 & 3,71 & Tinggi \\
\hline \multicolumn{7}{|c|}{ Total rata- rata skor } & 3,62 & Tinggi \\
\hline
\end{tabular}

Tabel 4. menunjukkan bahwa variabel dalam penelitian ini memiliki nilai koefisien korelasi lebih besar dari 0,3 pada seluruh item pernyataan. Artinya butirbutir pernyataan di dalam instrumen penelitian dinyatakan valid.

Data Tabel 5. menunjukkan bahwa ketiga variabel dalam penelitian ini memiliki nilai koefisien Cronbach's Alpha lebih besar dari 0,6. Hal tersebut menunjukkan pernyataan pada kuesioner reliabel dan dapat digunakan untuk 
melakukan penelitian. Berikut rincian Tabel 6. menyajikan hasil uji reliabilitas instrument.

Tabel 4.

Hasil Uji Validitas Instrumen

\begin{tabular}{|c|c|c|c|c|}
\hline No & Variabel & $\begin{array}{c}\text { Item } \\
\text { Pernyataan }\end{array}$ & $\begin{array}{c}\text { Koefisien } \\
\text { Korelasi Total }\end{array}$ & Keterangan \\
\hline \multirow[t]{8}{*}{1} & Perceived Quality (X) & $\mathrm{X} 1.1$ & 0,795 & Valid \\
\hline & & $\mathrm{X} 1.2$ & 0,740 & Valid \\
\hline & & $\mathrm{X} 1.3$ & 0,837 & Valid \\
\hline & & $\mathrm{X} 1.4$ & 0,849 & Valid \\
\hline & & $\mathrm{X} 1.5$ & 0,759 & Valid \\
\hline & & $\mathrm{X} 1.6$ & 0,797 & Valid \\
\hline & & $\mathrm{X} 1.7$ & 0,838 & Valid \\
\hline & & $\mathrm{X} 1.8$ & 0,795 & Valid \\
\hline \multirow[t]{4}{*}{2} & Perceived Risk (M) & M1.1 & 0,886 & Valid \\
\hline & & M1.2 & 0,903 & Valid \\
\hline & & M1.3 & 0,773 & Valid \\
\hline & & M1.4 & 0,915 & Valid \\
\hline \multirow[t]{4}{*}{3} & Perceived Value $(\mathrm{Y})$ & Y1.1 & 0,830 & Valid \\
\hline & & Y1.2 & 0,804 & Valid \\
\hline & & Y1.3 & 0,896 & Valid \\
\hline & & Y1.4 & 0,841 & Valid \\
\hline
\end{tabular}

Tabel 5.

Hasil Uji Reliabilitas Instrumen

\begin{tabular}{ccc}
\hline Variabel & Cronbach's Alpha & Keterangan \\
\hline Perceived Quality & 0,919 & Reliabel \\
Perceived Risk & 0,887 & Reliabel \\
Perceived Value & 0,864 & Reliabel \\
\hline
\end{tabular}

Sumber: Data diolah, 2018

Dalam penelitian ini, teknik analasis data yang digunakan adalah teknik analisis jalur (path Analysis). Teknik ini digunakan untuk mengetahui pengaruh langsung maupun tidak langsung seperangkat variabel bebas terhadap variabel terikat (Sani \& Maharani, 2013:74). Hasil analisis jalur secara rinci dijelaskan sebagai berikut:

Persamaan Sub-struktural 1

$$
\mathrm{M}=\beta_{1} \mathrm{X}+\mathrm{e}
$$

Persamaan Sub-struktural 2

$$
\mathrm{Y}=\beta_{2} \mathrm{X}+\beta_{3} \mathrm{M}+\mathrm{e}
$$

Tabel 6.

Hasil Analisis Jalur Persamaan Regresi 1

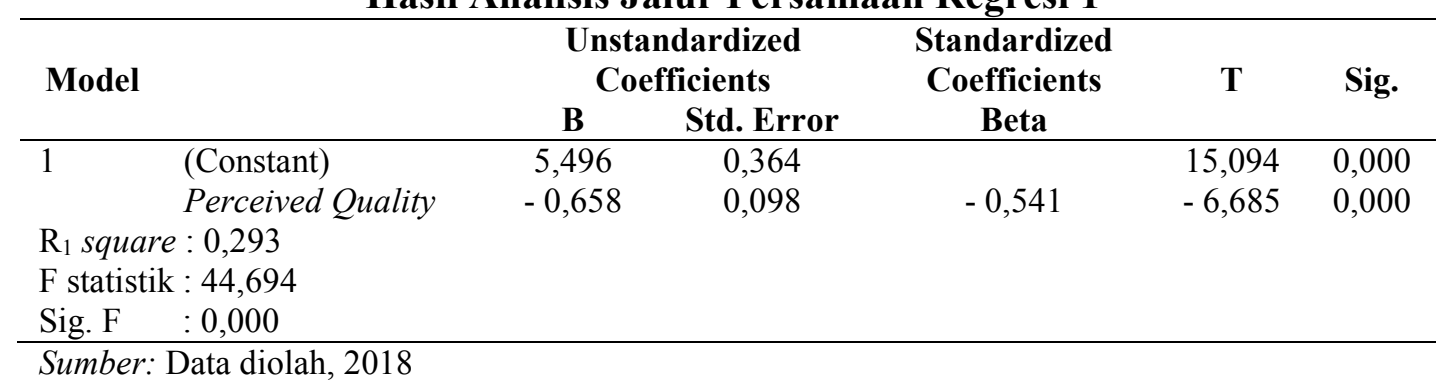


Berdasarkan hasil analisis jalur substruktur 1 seperti yang disajikan pada Tabel 7 maka persamaan strukturalnya adalah sebagai berikut:

$$
M=-0,541 X+e
$$

Nilai koefisien regresi variabel perceived quality adalah sebesar $-0,541$ memiliki arti perceived quality berpengaruh negatif terhadap perceived risk. Uji signifikansi t lebih kecil dari 0,05 yang menunjukkan bahwa perceived quality berpengaruh signifikan terhadap perceived risk. Besarnya pengaruh variabel bebas terhadap variabel terikat ditunjukkan oleh nilai determinasi total ( $R$ Square) sebesar 0,293 yang memiliki arti bahwa sebesar 29,3 persen variasi perceived risk dipengaruhi oleh variasi perceived quality, sedangkan sisanya yakni sebesar 70,7 persen dijelaskan oleh faktor lain yang tidak dimasukkan kedalam model.

Tabel 7.

Hasil Analisis Jalur Persamaan Regresi 2

\begin{tabular}{|c|c|c|c|c|c|c|}
\hline \multirow[t]{2}{*}{ Model } & & \multicolumn{2}{|c|}{$\begin{array}{c}\text { Unstandardized } \\
\text { Coefficients }\end{array}$} & \multirow{2}{*}{$\begin{array}{c}\text { Standardized } \\
\text { Coefficients } \\
\text { Beta }\end{array}$} & \multirow[t]{2}{*}{$\mathbf{T}$} & \multirow[t]{2}{*}{ Sig. } \\
\hline & & B & Std. Error & & & \\
\hline \multirow[t]{3}{*}{1} & (Constant) & 1,584 & 0,360 & & 4,399 & 0,000 \\
\hline & Perceived Quality & 0,736 & 0,066 & 0,690 & 11,226 & 0,000 \\
\hline & Perceived Risk & $-0,213$ & 0,054 & $-0,242$ & $-3,940$ & 0,000 \\
\hline \multicolumn{7}{|c|}{$\mathrm{R}_{2}$ square $: 0,715$} \\
\hline \multicolumn{7}{|c|}{ F statistik : 133,902} \\
\hline Sig. F & : 0,000 & & & & & \\
\hline
\end{tabular}

Nilai koefisien variabel perceived quality sebesar 0,690 yang memiliki arti variabel perceived quality berpengaruh positif terhadap perceived value. Uji signifikansi t yang kurang dari 0,05 menunjukkan bahwa variabel perceived quality berpengaruh signifikan terhadap perceived value.

Nilai koefisien variabel perceived risk sebesar -0,242 yang memiliki arti variabel perceived risk berpengaruh negatif terhadap variabel perceived value. Uji signifikansi t yang kurang dari 0,05 menunjukkan bahwa variabel perceived risk berpengaruh signifikan terhadap variabel perceived value. Besarnya pengaruh variabel bebas terhadap variabel terikat ditunjukkan oleh nilai determinasi total $(\mathrm{R}$ square) sebesar 0,715. Hal ini menunjukkan bahwa 71,5 persen variasi perceived value dipengaruhi oleh variabel perceived quality dan perceived risk, sedangkan sisanya yakni sebesar 28,5 persen dijelaskan oleh faktor lain yang tidak dimasukkan ke dalam model.

Berdasarkan model substruktur 1 dan substruktur 2, maka dapat disusun model diagram jalur akhir. Sebelum menyusun model diagram jalur akhir, nilai standar error harus dihitung terlebih dahulu. Perhitungan standar error adalah sebagai berikut:

$$
\mathrm{e}_{\mathrm{i}}=\sqrt{1-R i^{2}}
$$




$$
\begin{aligned}
\mathrm{e}_{1} & =\sqrt{1-R 1^{2}}=\sqrt{1-0,293}=0,840 \\
\mathrm{e}_{2} & =\sqrt{1-R 2^{2}} \ldots \ldots \ldots \ldots \ldots \ldots \ldots \ldots \ldots \ldots \\
& =\sqrt{1-0,715}=0,533
\end{aligned}
$$

Pada perhitungan standar error, di dapat hasil $\mathrm{e}_{1}=0,840$ dan $\mathrm{e}_{2}=0,533$. Nilai koefisiensi determinasi total dapat dihitung sebagai berikut:

$$
\begin{aligned}
\mathrm{R}^{2} \mathrm{~m} & =1-\left(\mathrm{e}_{1}\right)^{2}\left(\mathrm{e}_{2}\right)^{2} \ldots \ldots \ldots \ldots \\
& =1-(0,840)^{2}(0,533)^{2} \\
& =1-(0,706)(0,284) \\
& =1-0,20054=0,799
\end{aligned}
$$

Nilai determinasi total sebesar 0,799 mempunyai arti bahwa sebesar 79,9 persen variasi perceived value dipengaruhi dipengaruhi oleh perceived quality dan perceived risk, sedangkan sisanya yakni sebesar 20,1 persen dipengaruhi oleh faktor lain yang tidak dijelaskan ke dalam model.

Pengaruh variabel Perceived quality (X) terhadap Perceived value (Y) dengan Perceived risk (M) sebagai variabel perantara :

$$
\begin{aligned}
& \mathrm{IE}=\beta_{1 \times} \times \beta_{3} \ldots \ldots \ldots \ldots \ldots \\
& \mathrm{IE}=-0,541 \times-0,242 \\
& \mathrm{IE}=0,130
\end{aligned}
$$

Hasil pengaruh tidak langsung perceived quality melalui perceived risk terhadap perceived value sebesar 0,130 . Hal ini berarti bahwa perceived risk berpengaruh secara tidak langsung sebesar 13 persen antara hubungan perceived quality terhadap perceived value.

Total pengaruh variabel perceived quality $(\mathrm{X})$ terhadap perceived value $(\mathrm{Y})$ melalui perceived risk $(\mathrm{M})$ dirumuskan sebagai berikut :

$$
\begin{aligned}
\mathrm{TE} & =\beta_{2}+\left(\beta_{1} \times \beta_{3}\right) \ldots \ldots \ldots \ldots \ldots \ldots \\
\mathrm{TE} & =0,690+(-0,242 \times-0,541) \\
\mathrm{TE} & =0,690+0,130 \\
\mathrm{TE} & =0,820
\end{aligned}
$$

Hasil perhitungan diatas menunjukkan pengaruh langsung perceived quality terhadap perceived value sebesar 0,690, sedangkan pengaruh tidak langsung perceived quality terhadap perceived value melalui perceived risk sebesar 0,130, karena pengaruh langsung lebih besar dibandingkan pengaruh tidak langsung, artinya perceived value melalui perceived risk berpengaruh langsung signifikan terhadap perceived value. Pengaruh total sebesar 0,820 menunjukkan bahwa variabel perceived quality mempengaruhi perceived value sebesar 82 persen yang dimediasi oleh perceived risk.

Pada hasil analisis pengaruh perceived quality terhadap perceived value diperoleh nilai koefisien $\beta_{2}$ sebesar 0,690 dan signifikansi t 0,000. Hal ini berarti $\mathrm{H}_{0}$ ditolak dan $\mathrm{H}_{1}$ diterima, artinya perceived quality berpengaruh positif signifikan terhadap perceived value.

Pada hasil analisis pengaruh perceived quality terhadap perceived risk diperoleh nilai koefisien $\beta_{1}$ sebesar $-0,541$ dan signifikansi t 0,000 . Hal ini berarti 
$\mathrm{H}_{0}$ ditolak dan $\mathrm{H}_{2}$ diterima, artinya perceived quality berpengaruh negatif signifikan terhadap perceived risk.

Pada hasil analisis pengaruh perceived risk terhadap perceived value diperoleh nilai koefisien $\beta_{3}$ sebesar $-0,242$ dan signifikansi t 0,000 . Hal ini berarti $\mathrm{H}_{0}$ ditolak dan $\mathrm{H}_{3}$ diterima, artinya perceived risk berpengaruh negatif signifikan terhadap perceived value.

Perhitungan pengaruh antar variabel ditunjukkan pada Tabel 8. berikut:

Tabel 8.

Pengaruh Langsung dan Pengaruh Tidak Langsung serta Pengaruh Total Perceived Quality (X), Perceived Risk (M), dan Perceived Value (Y)

\begin{tabular}{lccc}
\hline \multicolumn{1}{c}{ Pengaruh Variabel } & \multicolumn{3}{c}{$\begin{array}{c}\text { Pengaruh } \\
\text { Tidak } \\
\text { Langsung } \\
\text { Melalui } \\
\text { Perceived } \\
\text { Risk }\end{array}$} \\
$\begin{array}{lccc}\text { Langsung } \\
\text { Perceived quality } \rightarrow \text { perceived risk }\end{array}$ & $\begin{array}{c}\text { Pengaruh } \\
\text { Total }\end{array}$ \\
Perceived quality $\rightarrow$ perceived value & $-0,541$ & - & $-0,541$ \\
Perceived risk $\rightarrow$ perceived value & 0,690 & 0,130 & 0,820 \\
\hline Sumber: Data diolah, 2018 & $-0,242$ & - & $-0,242$ \\
\hline
\end{tabular}

Uji Sobel dilakukan untuk menguji peran variabel mediasi yang diberikan oleh perceived risk, maka pengujian signifikansi variabel mediasi dalam model dapat diperiksa dari hasil uji pengaruh tidak langsung. Uji sobel dihitung menggunakan microsoft excel 2010. Variabel perceived risk dinilai secara signifikan mampu memediasi pengaruh perceived quality terhadap perceived value, jika nilai koefisien $\mathrm{Z}$ lebih besar dari 1,96. Uji sobel dihitung dengan persamaan sebagai berikut :

$Z=\frac{\mathrm{ab}}{\sqrt{\mathrm{b}^{2} s_{a}^{2}+a^{2} s_{b}^{2}+s_{a}^{2} s_{b}^{2}}}$

Keterangan :

$\mathrm{a}=-0,541$

$\mathrm{s}_{\mathrm{a}}=0,098$

$\mathrm{b}=-0,242$

$\mathrm{Sb}=0,054$

$\mathrm{Z}=\frac{(-0,541)(-0,242)}{\sqrt{(-0,242)^{2}(0,098)^{2}+(-0,541)^{2}(0,054)^{2}+(0,098)^{2}(0,054)^{2}}}$

$Z=\frac{0,1309}{0,0379}$

$\mathrm{Z}=3,4454$

Hasil uji sobel yang telah dihitung menemukan hasil bahwa $Z=3,4454$ lebih besar dari 1,96 dengan tingkat signifikansi $0,000<0,05$. Hal ini menyatakan bahwa $\mathrm{H}_{0}$ ditolak dan $\mathrm{H}_{4}$ diterima, artinya perceived risk sebagai variabel mediasi dinilai secara positif signifikan mampu memediasi pengaruh perceived quality terhadap perceived value, serta variabel mediasi dalam penelitian ini termasuk 
mediasi sebagian (partial mediation). Hal tersebut karena pengaruh variabel perceived quality terhadap variabel perceived risk adalah signifikan, pengaruh variabel perceived risk terhadap perceived value adalah signifikan, pengaruh langsung variabel perceived quality terhadap variabel perceived value dengan melibatkan variabel perceived risk adalah signifikan, dan pengaruh langsung variabel perceived quality terhadap variabel perceived value tanpa melibatkan variabel perceived risk.

Penelitian ini dilakukan dengan tujuan untuk mengetahui pengaruh perceived quality terhadap perceived value. Berdasarkan hasil olah data diperoleh nilai koefisien beta positif sebesar 0,690 dengan tingkat signifikansi 0,000 (kurang dari 0,05$)$ yang artinya $\mathrm{H}_{1}$ diterima. Hal ini menunjukkan bahwa variabel perceived quality secara positif signifikan berpengaruh terhadap variabel perceived value. Hasil ini berarti semakin baik perceived quality (pelayanan) LPD Desa Adat Jro Kuta Pejeng, maka akan semakin tinggi perceived value (manfaat) yang dirasakan oleh nasabah.

Nilai (value) nasabah sangat dipengaruhi oleh perceived quality terhadap produk atau jasa yang ditawarkan oleh perusahaan. Dalam penelitian (Wijaya et al., 2013) menemukan hasil bahwa perceived quality berpengaruh positif signifikan terhadap perceived value pengguna internet mobile. Artinya bila persepsi terhadap kualitas meningkat, maka perceived value pengguna akan meningkat secara signifikan, serta penelitian yang dilakukan Utomo \& Sanaji (2014) menemukan hasil perceived quality berpengaruh positif signifikan terhadap perceived value produk telepon seluler. Penelitian Najib et al. (2016) juga menyatakan bahwa perceived quality berpengaruh positif signifikan terhadap perceived value.

Penelitian ini dilakukan dengan tujuan untuk mengetahui pengaruh perceived quality terhadap perceived risk. Berdasarkan hasil olah data diperoleh nilai koefisien beta negatif sebesar 0,541 dengan tingkat signifikansi 0,000 (kurang dari 0,05 ) yang artinya $\mathrm{H}_{2}$ diterima. Hal ini menunjukkan bahwa variabel perceived quality secara negatif signifikan berpengaruh terhadap variabel perceived risk. Hasil ini berarti semakin baik perceived quality (pelayanan) LPD Desa Adat Jro Kuta Pejeng, maka akan semakin rendah perceived risk (risiko) nasabah dalam menggunakan jasa LPD.

Nilai nasabah dibentuk oleh perceived quality dan perceived risk. Nasabah memberikan nilai tentang jasa yang memiliki keunggulan (Tsiotsou, 2005). Dalam penelitian yang dilakukan oleh Snoj et al. (2004) menemukan bahwa perceived quality berpengaruh negatif signifikan terhadap perceived risk. Hal tersebut juga ditemukan dalam penelitian Beneke et al. (2013) yang menyatakan bahwa perceived quality berpengaruh negatif signifikan terhadap perceived risk, serta penelitian Wang \& Yi (2015) menyatakan perceived quality berpengaruh negatif signifikan terhadap perceived risk.

Penelitian ini dilakukan dengan tujuan untuk mengetahui pengaruh perceived risk terhadap perceived value. Berdasarkan hasil olah data diperoleh nilai koefisien beta negatif sebesar 0,242 dengan tingkat signifikansi 0,000 (kurang dari 0,05 ) yang artinya $\mathrm{H}_{3}$ diterima. Hal ini menunjukkan bahwa variabel perceived risk secara negatif signifikan berpengaruh terhadap variabel perceived 
value. Hasil ini berarti semakin rendah perceived risk (risiko) yang dirasakan oleh nasabah, maka akan semakin tinggi perceived value (manfaat) yang diperoleh.

Dalam membeli barang atau jasa terdapat hal yang tidak pasti (risk) sehingga menimbulkan kekhawatiran bagi seseorang. Penelitian Xue (2015) menyatakan perceived risk adalah risiko yang dirasakan secara nyata setelah proses pembelian barang atau jasa. Snoj et al. (2004) menemukan perceived risk berpengaruh negatif signifikan terhadap perceived value. Dalam penelitian dilakukan Yang \& Wang (2014) menemukan bahwa dimensi-dimensi perceived risk berpengaruh negatif terhadap perceived value, serta Xue (2015) bahwa perceived risk berpengaruh negatif signifikan terhadap perceived value.

Penelitian ini dilakukan dengan tujuan untuk mengetahui pengaruh perceived risk dalam memediasi pengaruh perceived quality terhadap perceived value. Berdasarkan hasil olah data diperoleh nilai koefisien beta positif sebesar 0,820 dengan tingkat signifikansi 0,000 (kurang dari 0,05 ) yang artinya $\mathrm{H}_{1}$ diterima. Hal ini menunjukkan bahwa variabel perceived risk berpengaruh dalam memediasi pengaruh perceived quality terhadap perceived value secara positif signifikan. Hasil ini berarti semakin rendah perceived risk (risiko) nasabah, maka akan semakin baik perceived quality dan semakin tinggi perceived value nasabah.

Hasil penelitian ini sama dengan hasil-hasil penelitian sebelumnya yang telah dilakukan oleh Snoj et al. (2004), Vera (2015), dan Agrawal \& Teas (2004) yang menunjukkan bahwa perceived risk berpengaruh dalam memediasi pengaruh perceived quality terhadap perceived value secara positif signifikan.

Implikasi penelitian adalah untuk menekankan pada manfaat nyata dari hasil penelitian untuk meningkatkan perceived value dengan mengurangi perceived risk dan meningkatkan perceived quality pada nasabah LPD Desa Adat Jro Kuta Pejeng. Implikasi penelitian ini mencakup dua hal yaitu implikasi teoritis dan implikasi praktis. Implikasi teoritis berhubungan dengan kontribusi bagi perkembangan-perkembangan teori mengenai variabel perceived quality, perceived risk, dan perceived value. Implikasi praktis dalam penelitian ini berhubungan dengan kontribusi kepada pihak yang memberikan pelayanan LPD Desa Adat Jro Kuta Pejeng sebagai bahan pertimbangan dalam merumuskan kebijakan yang berhubungan dengan perceived quality dan perceived risk untuk menciptakan perceived value nasabah.

Berdasarkan penelitian yang telah dilakukan dapat diketahui bahwa secara teoritis, penelitian ini secara keseluruhan mendukung beberapa teori yang telah ada sebelumnya. Penelitian ini diharapkan memberikan kontribusi empiris tentang hubungan variabel perceived quality, perceived risk, dan perceived value bagi pengembangan ilmu di bidang manajemen pemasaran. Data diolah dengan teknik analisis jalur (path analysis) untuk memperkirakan hubungan kausalitas antar variabel-variabel yang telah ditetapkan sebelumnya.

Penelitian ini juga menggunakan uji sobel untuk menguji kekuatan pengaruh tidak langsung perceived quality $(\mathrm{X})$ terhadap perceived value $(\mathrm{Y})$ melaui variabel perceived risk (M). Hasil penelitian ini diharapkan dapat digunakan untuk memperkaya referensi dan ilmu pengetahuan yang berkaitan dengan variabel perceived quality, perceived risk, dan perceived value. 
Hasil penelitian ini diharapkan dapat menjadi referensi bagi LPD Desa Adat Jro Kuta Pejeng untuk lebih meningkatkan perceived quality sehingga mampu mengurangi pereceived risk serta meningkatkan perceived value nasabah. Pada variabel perceived quality menunjukkan bahwa LPD Desa Adat Jro Kuta Pejeng telah mampu memberikan pelayanannya cukup baik seperti, LPD Desa Adat Pejeng menjaga kebersihan kantor, penampilan karyawan yang rapi saat melayani nasabah, LPD Desa Adat Pejeng mampu memberikan pelayanan yang segera, LPD Desa Pejeng mampu memberikan pelayanan yang akurat, karyawan melayani dengan sikap yang ramah, serta karyawan LPD yang melayani dengan penuh perhatian. Pada variable perceived risk LPD Desa Adat Jro Kuta Pejeng perlu hati-hati dalam melakukan pencatatan untuk mengurangi kerugian nasabah.

Keterbatasan penelitian yang dapat diambil dari penelitian ini adalah sebagai berikut: Ruang lingkup penelitian hanya dilakukan di LPD Desa Adat Jro Kuta Pejeng dengan jumlah sampel sebanyak 110 orang, sehingga hasil dari penelitian tidak dapat digeneralisasi pada LPD di Kabupaten Gianyar dan LPD diluar Kabupaten Gianyar. Faktor yang mempengaruhi perceived value dalam penelitian ini adalah perceived quality dan perceived risk, sedangkan masih banyak faktor lain yang mempengaruhi perceived value seperti brand image, perceived price, dan perceived usefulness. Penelitian ini hanya dilakukan dalam titik waktu tertentu (cross section), sedangkan lingkungan setiap saat berubah (dinamis), sehingga penelitian ini penting untuk dilakukan kembali di masa mendatang.

\section{SIMPULAN}

Perceived quality berpengaruh positif signifikan terhadap perceived value. Hal ini berarti semakin baik perceived quality, maka akan semain tinggi perceived value nasabah. Perceived quality berpengaruh negatif signifikan terhadap perceived risk. Hal ini berarti semakin baik perceived quality, maka akan semakin rendah perceived risk nasabah. Perceived risk berpengaruh negatif signifikan terhadap perceived value. Hal ini berarti semakin rendah perceived risk, maka akan semakin tinggi perceived value nasabah. Perceived risk berperan sebagai partial mediation pada perceived quality terhadap perceived value berpengaruh secara positif signifikan. Hal ini berarti semakin rendah perceived risk, maka akan semakin baik perceived quality dan semakin tinggi perceived value nasabah.

Perceived quality nasabah LPD Desa Adat Jro Kuta Pejeng, secara umum sudah baik, namun diharapkan dapat meningkatkan pelayanannya. Berdasarkan hasil jawaban nasabah menunjukkan bahwa pelayanan yang perlu ditingkatkan yakni pelayanan karyawan dalam mengatasi keluhan nasabah, serta pelayanan karyawan dalam menjelaskan tentang kredit jangka panjang kepada nasabah.

LPD Desa Adat Jro Kuta Pejeng diharapkan dapat mengurangi kerugian nasabah dalam melakukan transaksi seperti kesalahan pencatatan saat melakukan transaksi, sehingga perceived risk yang dirasakan nasabah semakin rendah.

\section{REFERENSI}

Agrawal, S., \& Teas, R. K. (2004). Cross-National Applicability of a Perceived Risk Value model. Journal of Product and Brand Management, 13(4), 242- 
256.

Akdeniz, A. (2015). Effect of Perceived Values on The Brand Preference and The Purchase Intention. European Scientific Journal, 8(17), 1-17.

Ariyanti, K., \& Iriani, S. S. (2014). Pengaruh Persepsi Nilai dan Persepsi Risiko Terhadap Niat Beli Kosmetik Organik. Jurnal Ilmu Manajemen, 2(4), 11861196.

Beneke, J., Flynn, R., Greig, T., \& Mukiwa, M. (2013). The Influencer Of Perceived Product Quality, Relative Price And Risk On Customer Value And Willingness To Buy: A Study Of Private Label Merchandise. Journal Of Product And Brand Management, 22(3), 218-228.

Bobalca, C. (2014). Determinants of Customer loyalty: A Theoretical Approach. Journal of International Scientific Publications, Economic and Business, 8, 995-1005.

Choi, J. E., \& Kim, S. H. (2013). Persepsi nasabah terhadap kualitas produk dan jasa mempengaruhi value, dan penilaian positif terhadap suatu produk menciptakan persepsi positif terhadap suatu produk. International Journal Of Smart Home, 7(1).

Dewi, A. A. I. A. A. (2014). Eksistensi Oyonomi Desa Pekraman Dalam Perspektif Pluralisme Hukum. Jurnal Magister Hukum Udayana, 7(3), 515528.

Gunawan, K. (2011). Peran Falsafah Tri Hita Karana Bagi Pertumbuhan dan Kinerja Perkreditan Desa (LPD) di Bali. Analisis Manajemen, 5(2), 23-36.

Hapsari, R., Clemes, M., \& Dean, D. (2016). The Mediating Role of Perceived Value on the Relationship between Service Quality and Customer Satisfaction: Evidence from Indonesian Airline Passengers. Procedia Economics and Finance, 35, 388-395.

Hidayat, R. (2009). Pengaruh Kualitas Layanan, Kualitas Produk dan Nilai Nasabah Terhadap Kepuasan dan Loyalitas Nasabah Bank Mandiri. Jurnal Manajemen Dan Kewirausahaan, 11(1), 59-72.

Ikramuddin, Adam, M., Sofian, H., \& Faisal. (2017). The Relationship of Perceived Value, Service Quality, Brand Trust, and Brand Loyalty: A Literature Review. Expert Journal of Marketing, 5(2), 72-77.

Indrayani, L., \& Nurcaya, I. N. (2014). Peran Persepsi Kualitas Produk dalam Memediasi Pengaruh Gaya Hidup Terhadap Niat Beli Handphone Samsung Galaxy di Kota Denpasar. E-Jurnal Manajemen Unud, 3(4), 885-901.

Karwini, N. K., \& Suryanto, I. W. D. (2016). Analisis Kualitas Pelayanan dan 
Dampaknya terhadap Kepuasan Nasabah pada Lembaga Perkreditan Desa (LPD) Desa Adat Tibubiu Kerambitan Tabanan. Prosiding Seminar Nasional Hasil Penelitian-Denpasar, 220-246. Retrieved from https://ojs.stimihandayani.ac.id/index.php/PROSIDING/article/view/222. Diakses tanggal 20 juli 2018.

Kristanto, F. (2018). Aset Lembaga Perkreditan Desa Bali Tumbuh 22,5\%. Kabar24.Bisnis.Com. Retrieved from https://kabar24.bisnis.com/read/20180207/78/735888/aset-lembagaperkreditan-desabali-tumbuh-225. Diakses tanggal 23 Juli 2018.

Kurniawan, A. R., \& Idris. (2015). Analisis Pengaruh Citra Merek, Persepsi Kualitas, Dan Persepsi Resiko Terhadap Keputusan Pembelian Melalui Persepsi Nilai Sebagai Intervening (Studi Kasus Pada Honda Freed di Kota Semarang). Jurnal Studi Manajemen Dan Organisasi, 12, 53-62.

Lai, T. L. (2004). Service Quality and Perceived Value's Impact on Satisfaction, Intention and Usage of Short Message Service (SMS). Information System Frontiers, 6(4), 353-368.

Lee, Y. L. (2017). Discussion Consumers Perceived Value, Quality and Riskon Purchase Decision-Making From The Perspective Of Brand Image. International Journal of Management and Applied Science, 3(7), 32-34.

Lomboan, L. K. (2017). Analysis The Influence of Perceived, Perceived Price and Perceived Value on Consumer Purchase Intention In Traditional Fabrics (Case Study Kaeng Manado). Jurnal Berkala Ilmiah Efisiensi, 17(1), 100112 .

Marakanon, L., \& Panjakajornsak, V. (2017). Perceived quality, perceived risk and customer trust affecting customer loyalty of environmentally friendly electronics products. Kasetsart Journal of Social Sciences, 38(1), 24-30.

Martini, L. K. B., \& Kepramarini, P. (2015). Pengembangan Soft Skill Sumber Daya Manusia Pada Lembaga Perkereditan Desa. Jurnal Bakti Saraswati, $4(2), 122-127$.

Naami, A., Rahimi, Z., \& Ghandvar, P. (2017). The Effect of Perceived Value, Perceived Risk, and Price on Customers Buying Intention (Case Study: Employees of Presov Electronics Company). International Review of Management and Marketing, 7(5), 164-170.

Najib, M. A., Soesanto, H., \& Sukresna, I. M. (2016). Analisis Pengaruh Brand Awerness, dan Perceived Value Terhadap Keputusan Pembelian. Jurnal Sains Pemasaran Indonesia, 15(1), 62-73.

Potret LPD di Bali Kekayaan Rp 155 T Bangkrut Terbanyak di Tabanan. (2017). 
Www.Posbali.Id. Retrieved from https://www.posbali.id/potret-lpd-di-balikekayaan-rp155-t-bangkrut-terbanyak-di-tabanan. Diakses tanggal 18 Juli 2018

Ramantha, I. W. (2003). Menuju LPD Sehat. Buletin Studi Ekonomi Volume 11 Nomor 1 Tahun 2003.

Rauf, M. A. (2016). Politik Hukum Pembentukan Desa Adat dalam Sistem Pemerintahan di Indonesia. De Lega Lata, 1(2).

Sadiartha, A. A. N. G. (2017). Lembaga Perkreditan Desa sebagai Penopang Keajegan Budaya Ekonomi Masyarakat Bali. Jurnal Kajian Bali, 7(2), 1-18.

Sani, A., \& Maharani, V. (2013). Metodologi Penelitian Manajemen Sumber Daya Manusia. Malang: UIN Press.

Sari, N. P. S. N., Kerti Yasa, N. N., \& Nurcaya, I. N. (2015). Peran Kepercayaan Dalam Memediasi Pengaruh Persepsi Risiko Terhadap Niat Beli. Juima, 5(1), 77-88.

Sciffman, \& Kanuk. (2008). Perilaku konsumen (7th ed.). Jakarta: Indeks.

Snoj, B., Korda, A. P., \& Mumel, D. (2004). The Relationship Among Perceived Quality, Perceived Risk, dan Perceived Product Value. Journal of Product and Brand Management, 13(3), 156-167.

Suarni, G. A. P., Trupalupi, L. E., \& Haris, I. A. (2014). Analisis Faktor Yang Mempengaruhi Keputusan Nasabah Dalam Pengambilan Kredit Pada LPD (Lembaga Perkreditan Desa) Desa Pakraman Manggissari. Jurnal Pendidikan Ekonomi Undiksha, 4(1), 1-10.

Suaslioni, N. L. A., Atmadja, A. T., \& Wahyuni, M. A. (2017). Faktor-Faktor Yang Mempengaruhi Terjadinya Fraud Pada LPD Desa Pakraman Bontihing. E-Journal S1 Ak Universitas Pendidikan Ganesha, 8(2), 1-10.

Sundarianingsih, P. (2014). Evaluasi Keberhasilan Lembaga Perkreditan Desa (LPD) dalam Menggerakkan Sosial Ekonomi Masyarakat Pedesaan (Studi Pada Lembaga Perkreditan Desa (LPD) Desa Adat Pekutatan). Jurnal Ekonomi Pembangunan, 12(1), 70-85.

Surata, I. N. (2011). Penerapan Sanksi Adat Oleh Desa Pakraman Dalam Pengelolaan Lembaga Perkreditan Desa (LPD). Jurnal Sains Dan Teknologi, 11(1), 58-66.

Tjiptono, F., \& Chandra, G. (2012). Pemasaran Strategik (2nd ed.). Yogyakarta: Andi.

Tsiotsou, R. (2005). The role of perceived product quality and overall satisfaction 
on purchase intentions. International Journal of Consumer Studies. https://doi.org/10.1111/j.1470-6431.2005.00477.x. Diakses tanggal 20 Juli 2018 .

Utomo, E. A. S., \& Sanaji. (2014). Pengaruh Country Of Origin Dan Persepsi Kualitas Terhadap Persepsi Nilai Pada Produk Telepon Seluler. Jurnal Bisnis Dan Manajemen, 6(2), 114-121.

Vera, J. (2015). Perceived Brand Quality As A Way To Superior Customer Perceived Value Crossing By Moderating Effect. Journal Of Product And Brand Management, 24(2), 147-156.

Wang, Y. H., \& Yi, N. C. (2015). Does Internet Information Influence Fund Investors' Purchase Intention? Review Of Business and Finance Studies, 6(2), 11-19.

Wijaya, A., Samuel, H., \& Japriant, E. (2013). Analisa Pengaruh Perceived Quality Terhadap Perceived Value Konsumen Pengguna Internet Mobile XL di Surabaya. Jurnal Pemasaran Petra, 1(1), 1-12.

Xue, D. F. (2015). Analyzing the Relationship Between Perceived Risk and Customer Involvement: Based on the Bank Financial Products. International Journal of Economics, Commerce and Management United Kingdom, III(2), $1-7$.

Yamin, R. (2013). Persepsi Nilai, Persepsi Kualitas, dan Citra terhadap Kepuasan Konsumen pada PT. Astra International Daihatsu di Manado. Jurnal EMBA, 1(3), 1231-1240.

Yang, D., \& Wang, X. (2014). Understanding Perceived Risks In Mobile Payment Accaptance. Industrial Management \& Data System, 4(1), 1-28.

Yanti, F. A. K., \& Suryantini, N. P. S. (2015). Pengaruh Dana Pihak Ketiga, Kecukupan Modal, Risiko Kredit Dan Likuiditas Terhadap Profitabilitas LPD Kabupaten Badung. E-Jurnal Manajemen Unud, 12(4), 4362-4391. 